\title{
Serological Studies of Aeromonas hydrophila in Bangladesh
}

\section{Md. Robiul Islam¹, Mamnur Rashid $\mathbf{M}^{2}$, Md. Hashmi Sakib ${ }^{3 *}$ and Most. Waheda Rahman Ansary ${ }^{4}$}

${ }^{1}$ MS Scholar, Department of Aquaculture, Bangladesh Agricultural University, Mymensingh, Bangladesh

${ }^{2}$ Professor, Department of Aquaculture, Bangladesh Agricultural University, Mymensingh, Bangladesh

${ }^{3}$ Lecturer, Department of Agricultural Extension and Rural Development, EXIM Bank Agricultural University, Bangladesh

${ }^{4}$ Lecturer, Department of Biotechnology, EXIM Bank Agricultural University, Bangladesh

\begin{abstract}
Total collected 36 Aeromonas isolates from various healthy fishes of different regions in Bangladesh were characterized for their species and serogroup designations. After different morphological and biochemical characterization, it was found that, 25 of them were A. hydrophila. Serological studies were done by performing slide agglutination tests followed by agglutination titration. Agglutination ability of all the isolates (FKC and HKC) with 10 -fold and 20 -fold dilution of previously prepared anti $-A$. hydrophila rabbit serum were observed. We found 3 serotypes (serotype, A, B and C) from the tested 25 isolates form. The titers were 640-1280 (FKC) and 160-320 (HKC) for serotype A, 160-320 (FKC) and 80-160 (HKC) for serotype B. For serotype C, the titer was 20 (both FKC and $\mathrm{HKC}$ ).
\end{abstract}

Keywords: Aeromonas hydrophila; Bacterial disease; Agglutination titration; Serotype

\section{Introduction}

Bangladesh is a country of rivers so perhaps it's no surprise that fish is a staple of Bangladeshi food. There's a common saying: "Fish and rice make a Bangali" (Machh-e-bhat-e-Bangali). But bacterial fish diseases especially Aeromonas in freshwater causes great losses in fish [1,2]. In aquatic environment, Aeromonas are widely distributed. They are facultative, anaerobic, gram negative, rod shaped, motile and nonmotile, oxidase and catalase positive nitrate to nitrite reducing, glucose fermenting bacteria [3]. They are also part of the normal intestinal microflora of healthy fish [4]. Aeromonas is an important bacteria belonging to the family Aeromonadaceae.

Among Aeromonas spp., A. hydrophila, A. bestiarum, A. sorbia, A.veronii, A. salmonicida, A. jandaei, and A. allosaccharophila are devastating pathogen in both warm and cold blooded animals $[5,6]$. They are common contaminants in fish, a variety of raw meat, milk and milk products, and other raw [7,8]. They cause diseases not only in aquatic and terrestrial animals but also in human [9]. Farmed and wild freshwater fishes were frequently affected by A. hydrophila in different locations of Bangladesh [10,11]. They cause hemorrhagic septicemia or motile Aeromonas septicemia (MAS), infectious dropsy, red mouth disease and red pest disease in fish such as carp, rainbow trout, brown trout, salmon, eel, carp, channel catfish, tilapia, and goldfish [12,13]. Epizootic ulcerative syndrome (EUS) is also occurred by this microorganism [14]. There is strong evidence that fishes died of septicemia caused by bacterial pathogen, Aeromonas sp., notable $A$. hydrophila [15].

Aeromonas are phenotypically, serologically and genetically quite diverse. The conventional method of identifying these microorganisms is microbiological culture, biochemical tests, protein analysis, serotyping etc. The trend of measuring or monitoring antibody response in fish is increasing day by day. Different serological methods are available for this purpose. Agglutination titration test is commonly used [16]. Agglutination titration test was done by Rashid [17]. The assessment of agglutinating antibody titer is an easy approach to measure circulating antibodies in serum samples collected from fish [18]. So, considering above ideas the present investigation was undertaken with the following objectives: i) to know serology of $A$. hydrophila collected from different fishes of Bangladesh and ii) to facilitate rapid diagnosis of the disease caused by $A$. hydrophila.

\section{Materials and Methods}

\section{Collection of bacterial isolate}

A total number of 36 isolates of Aeromonas like bacteria were collected from 8 locations of Bangladesh. The isolates were collected from healthy fishes of different fish farms, beels and fish markets. The collected samples were streaked onto the the Tryptone Soya Agar (TSA) and Aeromonas selective growth medium (AIM). Then incubated at $25^{\circ} \mathrm{C}$ for $24 \mathrm{~h}$ and observed the growth of bacterial colony. Individual colonies were then separated from the plates on the basis of colour, shape and size. Further culture was done onto to the TSA plates again to obtain the pure culture of bacteria. After the growth of the bacteria the TSA slant bottles were preserved at $4^{\circ} \mathrm{C}$ as stocks.

Among 36 isolates, 7 isolates were isolated from Oreochromis mossambicus (tilapia), 5 isolates were isolated from native Anabas testudineus (koi), 2 isolates were isolated from Pangasius hypophthalmus (pungas), 4 isolates were isolated from Labio rohita (rohu), 2 isolates from Mottled nundus (veda), 3 isolates from Labeo bata (bata), one isolate was isolated from each of Colisa fasciatus (khalisha), Cirrhinus mrigala (mrigal) and Heteropneustes fossilis (shingh), 4 isolates from Channa punctatus (taki) and 6 isolates from Puntius sarana (punti). Source of collection and isolation of bacteria with laboratory code is shown in Table 1.

\section{Identification and characterization of Aeromonas like bacteria}

All grown colonies of Aeromonas like bacteria (fresh 24-

*Corresponding author: Hashmi Sakib, Lecturer, Department of Agricultural Extension and Rural Development, EXIM Bank Agricultural University, Bangladesh, Tel: 8801716176922, E-mail: sakib_20067@yahoo.com

Received April 17, 2015; Accepted May 07, 2015; Published June 30, 2015

Citation: Islam R, Mamnur Rashid M, Sakib H, Ansary MWR (2015) Serological Studies of Aeromonas hydrophila in Bangladesh. J Aquac Res Development 6: 351. doi:10.4172/2155-9546.1000351

Copyright: (c) 2015 Islam R, et al. This is an open-access article distributed under the terms of the Creative Commons Attribution License, which permits unrestricted use, distribution, and reproduction in any medium, provided the original author and source are credited. 
Citation: Islam R, Mamnur Rashid M, Sakib H, Ansary MWR (2015) Serological Studies of Aeromonas hydrophila in Bangladesh. J Aquac Res Development 6: 351. doi:10.4172/2155-9546.1000351

Page 2 of 5

\begin{tabular}{|c|c|c|c|}
\hline Area & No. of strains & Laboratory code & Source of isolation \\
\hline \multirow[t]{7}{*}{ Mymansingh } & \multirow[t]{7}{*}{7} & MP 811 & Intestine of healthy Puntius sarana (punti) \\
\hline & & MTi811 & Kidney of healthy Oreochromis mossambicus (tilapia) \\
\hline & & MPA911 & Intestine of healthy Pangasius hypophthalmus (pungas) \\
\hline & & MV811 & Muscle of healthy Mottled nundus (veda) \\
\hline & & MK911 & Liver of healthy Anabas testudineus (koi) \\
\hline & & MR911 & Kidney of healthy Labio rohita (rohu) \\
\hline & & MT1011 & Blood of healthy Channa punctatus (taki) \\
\hline \multirow[t]{6}{*}{ Gaibandha } & \multirow[t]{6}{*}{6} & GP711 & Intestine healthy $P$. sarana (punti) \\
\hline & & GTi811 & Kidney of healthy O. mossambicus (tilapia) \\
\hline & & GKh811 & Healthy Colisa fasciatus (khalisha) \\
\hline & & GR911 & Intestine of healthy L. rohita (rohu) \\
\hline & & GT911 & Intestine of healthy C. punctatus (taki) \\
\hline & & GB1011 & Intestine of healthy Labeo bata (bata) \\
\hline \multirow[t]{4}{*}{ Rangpur } & \multirow[t]{4}{*}{4} & RK811 & Healthy koi (A. testudineus) \\
\hline & & RM811 & Healthy Cirrhinus mrigala (mrigal) \\
\hline & & RS911 & Muscle of healthy Heteropneustes fossilis (shingh) \\
\hline & & RCC1011 & Kidney of healthy C. punctatus (taki) \\
\hline \multirow[t]{3}{*}{ Dinajpur } & \multirow[t]{3}{*}{3} & DV711 & Healthy $M$. nundus (veda) \\
\hline & & DK811 & Healthy A. testudineus (koi) \\
\hline & & DB711 & Intstine of healthy $L$. bata (bata) \\
\hline \multirow[t]{5}{*}{ Shirajgonj } & \multirow[t]{5}{*}{5} & ST811 & Healthy fish muscle of C. punctatus (taki) \\
\hline & & SP911 & Muscle of healthy $P$. sarana (punti) \\
\hline & & STI1011 & Kidney of healthy O. mossambicus (tilapia) \\
\hline & & SB1011 & Muscle of healthy $L$. bata (bata) \\
\hline & & SR1111 & Intestine of healthy L. rohita (rohu) \\
\hline \multirow[t]{4}{*}{ Trisal } & \multirow[t]{4}{*}{4} & TR911 & Intestine of healthy L. rohita (rohu) \\
\hline & & TTI911 & Kidney of healthy O. mossambicus (tilapia) \\
\hline & & TK811 & Healthy A. testudineus (koi) \\
\hline & & TP1011 & Kidney of healthy $P$. sarana (punti) \\
\hline \multirow[t]{4}{*}{ Netrokona } & \multirow[t]{4}{*}{4} & NTI911 & Kidney of healthy O. mossambicus (tilapia) \\
\hline & & NP911 & Muscle of healthy $P$. sarana (punti) \\
\hline & & NPa811 & Healthy P. hypophthalmus (pangas) \\
\hline & & NK111 & Intestine of healthy O. mossambicus (tilapia) \\
\hline \multirow[t]{3}{*}{ Rajshahi } & \multirow[t]{3}{*}{3} & RK811 & Healthy fish muscle of $A$. testudineus (koi) \\
\hline & & RTI811 & Intestine of healthy O. mossambicus (tilapia) \\
\hline & & RP811 & Healthy $P$. sarana (punti) \\
\hline
\end{tabular}

Table 1: List of Aeromonas with area and sources of isolation.

hour cultures) were taken from the streaked plates and then some morphological tests were done such as shape, size, Gram character, flagellation and motility. Biochemical characters such as, oxidase, catalase, oxidative-fermentative (OF) [19], acid and gas production from sugars (lactose, maltose, sucrose, Manitol, Inositol, Sorbitol and Rhamnose) [20], Esculin hydrolysis, methyl-red, Voges-Proskauer (VP), indole and $\mathrm{H}_{2} \mathrm{~S}$ production, Arginine decomposition, Lysine and Ornithine decarboxylase and citrate utilization [21] were studied to confirm their generic and specific natures. Physiological characters were checked by observing the growth of each isolate at temperatures of $4^{\circ} \mathrm{C}, 5^{\circ} \mathrm{C}, 37^{\circ} \mathrm{C}$ and $40^{\circ} \mathrm{C}$ and in different concentrations of $\mathrm{NaCl}$ such as $0 \%$ to $4 \%$ to confirm the characteristics of Aeromonas bacteria.

\section{Serological characterization}

Identified isolates of $A$. hydrophila were used after formalinized ( $0.5 \%$ formalin in PBS, referred as formalin-killed cells or FKC) or heat-treated (boiled for $2.5 \mathrm{~h}$ referred as heat-killed cells or HKC) and washed 3 times with PBS. For comparison isolate AQ508, isolated from diseased A. testudineus (koi) was used [1].

\section{Production of anti- $A$. hydrophila rabbit serum}

An anti-A. hydrophila AQ508 serum was produced in two white rabbit. At first formalin-killed cells were emulsified with Freund's complete adjuvant and then injected at multiple sites of rabbit followed by three subsequent booster injections at weekly intervals [22]. Agglutination titration of the serum sampled after each booster dose was checked using microtiter plates. The titer rose 1280 after the third booster dose. After the rabbit was sacrificed, the serum was collected, heat-inactivated $\left(58^{\circ} \mathrm{C}, 30 \mathrm{~min}\right)$ and stored $1.5 \mathrm{ml}$ in eppendorf tubes at $-20^{\circ} \mathrm{C}$

\section{Slide agglutination test}

Slide agglutination test of the live cells of 25 strains and 1 reference strain of $A$. hydrophila were carried out with the antiserum. The antiserum was diluted at 10- fold and 20-fold with SDW (sterilized distilled water). At first one drop of 10 - fold and 20 -fold diluted antiserum and one drop of PS (Physiological saline) were taken separately in a glass slide. Then one drop of FKC was added in each drop in the 
Citation: Islam R, Mamnur Rashid M, Sakib H, Ansary MWR (2015) Serological Studies of Aeromonas hydrophila in Bangladesh. J Aquac Res Development 6: 351. doi:10.4172/2155-9546.1000351

Page 3 of 5

glass slide. Finally it was moved forward and backward for five minutes. In this way slide agglutination of HKC was also done. The agglutination was then observed optically. The slide agglutination tests are shown in Figure 1 .

\section{Agglutination titration test}

Agglutination titration of the antiserum dilutions (5-fold, 10-fold and 20 -fold) against FKCs and HKCs of 25 strains of A. hydrophila were performed using micro-titer plates (96-well micro-titer plate, Figure 2). Antigen $(10 \mathrm{~mL}$ ) was prepared by mixing $100 \mathrm{~mL}$ freshly cultured bacterial colonies in $10 \mathrm{ml}$ sterile PBS homogenously.

Exact half of the prepared antigen was mixed with a drop of $0.5 \%$ formalin and kept at $37^{\circ} \mathrm{C}$ for $2 \mathrm{~h}$. Prepared mixed solution $(100 \mu \mathrm{l})$ was plated, and incubated at $25^{\circ} \mathrm{C}$ for $48 \mathrm{~h}$. Finally it was preserved at $4^{\circ} \mathrm{C}$ for future use. Another half was boiled for $2.5 \mathrm{~h}$ in water bath to prepare heat-killed cells (HKC) and preserved similarly. One drop of PBS $(10 \mu \mathrm{l})$ was dropped in each well of a 96-well micro- titer plate. One diluter was heated to red heat, cooled down in air and then 5-fold diluted antiserum was mixed with the PBS of all columns excluding the right sided $12^{\text {th }}$ column, which was kept as control. Two lines of microtiter plates were filled with one drop of FKC including the control. This same procedure was done for HKC. So, antiserum from two different sources could be tested by 8 lines. After adding antigens the microtiter plate was wrapped by plastic rapper and vibrated slowly by a plate vibrator for 5 minutes. Then it was kept at $37^{\circ} \mathrm{C}$ for $2 \mathrm{~h}$ and $4^{\circ} \mathrm{C}$ for overnight. Next morning the plate was observed over a tube light to record the agglutination. Dilution factor of the antigen ( 5 fold) was multiplied by 4 to make 20, which was assigned to the left most well. Then the number was doubled for the next well up to the $11^{\text {th }}$ well to

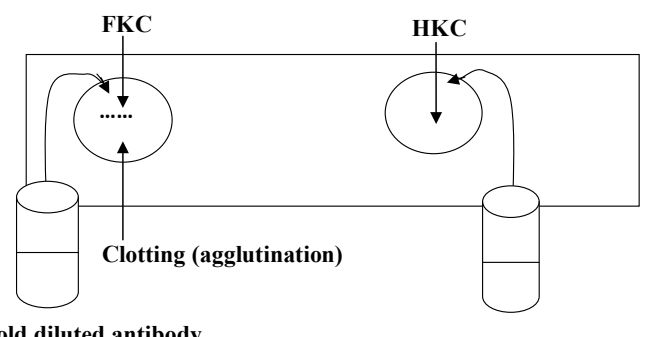

10 fold diluted antibody

Physiological saline

Figure 1: Slide agglutination test of Aeromonas like bacteria

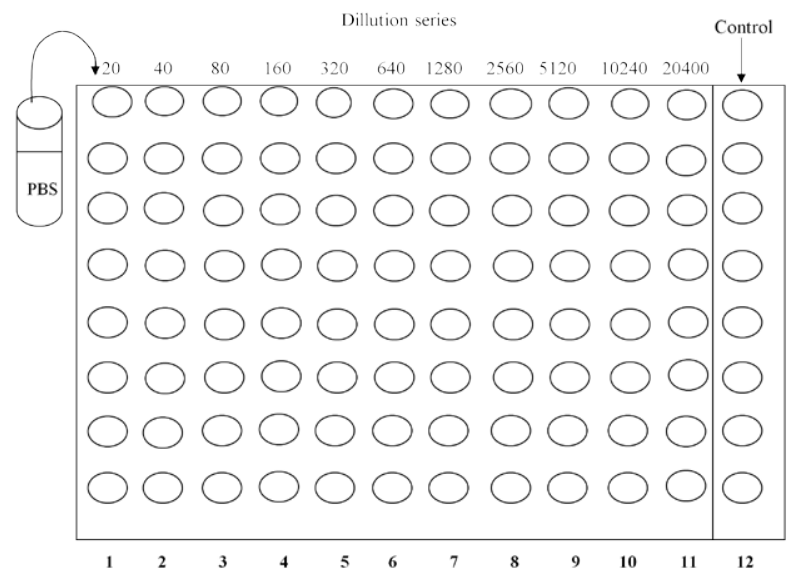

Figure 2: Agglutination titration test in micro-titer plates.

\begin{tabular}{|c|c|c|c|}
\hline Characters & $\begin{array}{l}\text { Characterization } \\
\text { by Popoff et al. }\end{array}$ & $\begin{array}{c}\text { Characterization } \\
\text { by Sabur }\end{array}$ & $\begin{array}{l}\text { Present } \\
\text { Results }\end{array}$ \\
\hline Gram stain & - & - & - \\
\hline Shape & Rod & Rod & Rod \\
\hline Motility & + & + & + \\
\hline Sensitivity to 0129 & ND & ND & - \\
\hline Oxidase & + & + & + \\
\hline Catalase & + & + & + \\
\hline OF test & $\mathrm{F}$ & $\mathrm{F}$ & $\mathrm{F}$ \\
\hline $\begin{array}{l}\text { Acid and gas production } \\
\text { from Glucose }\end{array}$ & + & + & + \\
\hline \multicolumn{4}{|l|}{ Acid production from } \\
\hline Lactose & + & + & + \\
\hline Sucrose & + & + & + \\
\hline Maltose & + & + & + \\
\hline Manitol & + & + & - \\
\hline Inositol & - & - & - \\
\hline Sorbitol & - & - & - \\
\hline Rhamnose & - & - & - \\
\hline Esculin hydrolysis & ND & ND & + \\
\hline Methyl-red test & - & - & - \\
\hline Voges-Proskaur & + & + & + \\
\hline Indole & + & + & + \\
\hline Arginine decomposition & + & + & + \\
\hline Lysine decarboxilation & - & - & - \\
\hline Ornithine decarboxilation & - & - & - \\
\hline Citrate utilization & + & + & + \\
\hline Growth at: $4^{\circ} \mathrm{C}$ & - & - & - \\
\hline $5^{\circ} \mathrm{C}$ & + & + & + \\
\hline $37^{\circ} \mathrm{C}$ & + & + & + \\
\hline $40^{\circ} \mathrm{C}$ & - & - & - \\
\hline
\end{tabular}

- : Negative, + : Positive, F : Fermentative, ND : Not done

Table 2: Similarities of collected isolates with A. hydrophila in comparison to Popoff and Sabur.

understand the strength of the titer. The right most well showing the agglutination would appear as power of the antibody (antibody titer).

\section{Results}

The present research was undertaken to investigate the serological differences among A. hydrophila strains by slide agglutination and agglutination titration test isolated from different fishes and places of Bangladesh using a reference strain AQ508 isolated from Anabas species.

\section{Characterization of collected isolates}

Different morphological and biochemical tests of the collected 36 Aeromonas like bacteria were done. Among 36 isolates, 25 were found as similar characteristics as A. hydrophila (Table 2). All 25 isolates were gram negative, motile, rod shape, oxidize and catalase positive and fermentative bacteria. They were hydrolyzed esculin and not sensitive to the vibriostatic agent 0129 . All 25 isolates produce acid from glucose, lactose sucrose and maltose. But they were unable to produce acid from manitol, inositol, sorbitol and rhamnose. They can produce indole where they were unable to decarboxilate lysine and ornithin. We found the similar result as Popoff et al. and Sabur or all the characters of 25 isolates $[19,23]$. The culture of isolated Aeromonas like bacteria was similar with the pure culture of preserved A. hydrophila. 
Citation: Islam R, Mamnur Rashid M, Sakib H, Ansary MWR (2015) Serological Studies of Aeromonas hydrophila in Bangladesh. J Aquac Res Development 6: 351. doi:10.4172/2155-9546.1000351

Page 4 of 5

\section{Slide agglutination test}

To observe the agglutination capacity slide agglutination test was done (Table 3). Among 25 isolates, 16 isolates (MP811, MTi811, MPa911, MV811, MK911, MR911, MT1011, TR911, TTi911, TK811, TP1011, GP711, GTi811, GKh811, GR911 and GT911) reacted positively in slide agglutination test with 10 - and 20 -fold dilutions of the antiserum. It indicates that, those 16 isolates were belongs to serotype A.

Four isolates (GB1011, RK811, RM811 and RCC1011) reacted positively in slide agglutination test with only 10 -fold dilution of the antiserum but not reacted positively with 20 -fold dilution of the antiserum. It reveals that, these 4 isolates were belongs to serotype $\mathrm{B}$. Only 5 isolates (ST811, SP911, DV711, NTTi911 and NPa811) were not reacted positively in slide agglutination test with 10 - and 20 -fold dilution of the antiserum. These isolates were belongs to serotype $\mathrm{C}$.

\section{Agglutination titration of bacterial isolates}

The distribution of the anti-A. hydrophila rabbit serum in agglutination titration test against FKC and $\mathrm{HKC}$ of the 25 strains are shown in Table 4. HKC were show lower titer than the FKC. In case of 11 isolates (MP811, MTi811, MPa911, MV811, MK911, MR911, MT1011, TR911, TTi911, TK811 and TP1011) the titers were 160320 for HKC and 640-1280 for FKC. The titers were 80-160 for HKC and 160-320 for FKC in case of 9 isolates (GP711, GTi811, GKh811, GR911, GT911, GB1011, RK811, RM811, and RCC1011). The titer was 20 for both HKC and FKC in case of 5 isolates (ST811, SP911, DV711, NTTi911 and NPa811). According to the above results of agglutination titers, the isolates of the titers ranged from 640-1280 for FKC and 160320 for $\mathrm{HKC}$ were grouped in serotype A. The isolates of the titers ranged from 160-320 for FKC and 80-160 for HKC were grouped in serotype $\mathrm{B}$. The isolates of the titer 20 for both FKC and HKC were grouped in serotype C (Figure 3 ).

\section{Discussion}

The ecology of $A$. hydrophila in fishes is quite different from one place to another. We found 25 A. hydrophila among 35 bacterial isolates. Though all the isolates were collected from healthy fishes, but we found the bacteria. Our result indicates that, A. hydrophila exists in the fishes and culture environment even when the disease did not occur. The water is the possible source of the infection. It also proved that, they are the part of the normal intestinal microflora of healthy fish. Before showing any symptom they remain within the fish body. But when any lesions occur in fish body, then the pathogen make it more serious. So, to reduce economic losses of fishes due to A. hydrophila, the fish farmer should keep it in mind.

Another finding of our experiment was the serological differences among 25 strains of $A$. hydrophila isolated from different fishes and places of Bangladesh. Among 25 strains, 11 isolates (P. sarana, MP811; O. mossambicus, MTi811; P. hypophthalmus, MPa911; M. nundus, MV811; A. testudineus, MK911; L. rohita, MR911; C. punctatus, MT1011; L. rohita, TR911; O. mossambicus, TTi911; A. testudineus, TK811 and P. sarana, TP1011) from Mymensingh and Trisal districts and 5 isolates (P. sarana, GP711; O. mossambicus, GTi811; A. testudineus, GKh811; L. rohita, GR911 and C. punctatus, GT911) from Gaibandha and Rangpur districts were serotype A in slide agglutination test. In case of agglutination titration only 11 isolates $(P$. sarana, MP811; O. mossambicus, MTi811; P. hypophthalmus, MPa911; M. nundus, MV811; A. testudineus, MK911; L. rohita, MR911; C. punctatus, MT1011; L. rohita, TR911; O. mossambicus, TTi911; A. testudineus, TK811 and P. sarana, TP1011) from Mymensingh and Trisal districts were serotype A. It's because of the concentration. Due to low concentration 5 isolates (P. sarana, GP711; O. mossambicus, GTi811; A. testudineus, GKh811; L. rohita, GR911 and C. punctatus, GT911) were belong to serotype B in agglutination titration test. Four isolates (L. bata, GB1011; A. testudineus, RK811; C. mrigala, RM811 and C. punctatus, RCC1011) from Gaibandha and Rangpur districts were serotype B. Five isolates (C. punctatus, ST811; P. sarana, SP911; M. nundus, DV711; O. mossambicus, NTTi911 and P. hypophthalmus, NPa811) from Sirajgong, Dinajpur and Netrakona districts were serotype $\mathrm{C}$ in both slide agglutination and agglutination titration test.

\begin{tabular}{|c|l|c|}
\hline $\begin{array}{c}\text { No. of } \\
\text { strains }\end{array}$ & Strain code with fish source & \multicolumn{2}{|c|}{$\begin{array}{c}\text { Agglutination } \\
\text { Distribution of antiserum }\end{array}$} \\
\hline 16 & $\begin{array}{l}\text { P. sarana (MP811), O. mossambicus (MTi811), P. hypophthalmus (MPa911), M. nundus (MV811), A. } \\
\text { testudineus (MK911), L. rohita (MR911), C. punctatus (MT1011), L. rohita (TR911), O. mossambicus } \\
\text { (TTi911), A. testudineus (TK811), P. sarana (TP1011), P. sarana (GP711), O. mossambicus (GTi811), }\end{array}$ & + \\
\hline $\begin{array}{l}\text { A. testudineus (GKh811), L. rohita (GR911) and C. punctatus (GT911) } \\
\text { 20-fold }\end{array}$ \\
\hline 4 & $\begin{array}{l}\text { L. bata (GB1011), A. testudineus (RK811), C. mrigala (RM811) and C. punctatus (RCC1011) } \\
+\end{array}$ & + \\
\hline 5 & $\begin{array}{l}\text { C. punctatus (ST811), P. sarana (SP911), M. nundus (DV711), O. mossambicus (NTTi911) and P. } \\
\text { hypophthalmus (NPa811) }\end{array}$ & - \\
\hline
\end{tabular}

- : Negative, + : Positive

Table 3: Slide agglutination of 25 isolates of $A$. hydrophila with the anti-A. hydrophila AQ508 rabbit serum.

\begin{tabular}{|c|l|c|c|}
\hline $\begin{array}{c}\text { No. of } \\
\text { Strains }\end{array}$ & Strain code with fish type & Serotype & \multicolumn{2}{|c|}{ Titer } \\
\hline 11 & $\begin{array}{l}\text { P. sarana (MP811), O. mossambicus (MTi811), P. hypophthalmus (MPa911), M. nundus (MV811), } \\
\text { A. testudineus (MK911), L. rohita (MR911), C. punctatus (MT1011), L. rohita (TR911), O. } \\
\text { mossambicus (TTi911), A. testudineus (TK811) and P. sarana (TP1011) }\end{array}$ & A & $640-1280$ \\
\hline 9 & $\begin{array}{l}\text { P. sarana (GP711), O. mossambicus (GTi811), A. testudineus (GKh811), L. rohita (GR911), } \\
\text { C. punctatus (GT911), L. bata (GB1011), A. testudineus (RK811), C. mrigala (RM811) and C. } \\
\text { punctatus (RCC1011) }\end{array}$ & B & $160-320$ \\
\hline 5 & $\begin{array}{l}\text { C. punctatus (ST811), P. sarana (SP911), M. nundus (DV711), O. mossambicus ( NTTi911) and P. } \\
\text { hypophthalmus (NPa811) }\end{array}$ & C & 20 \\
\hline
\end{tabular}

FK $^{\mathrm{a}}$ Formalin-killed cells; $\mathrm{HK}^{\mathrm{b}}$ Heat-killed cells

Table 4: Distribution of the anti-A. hydrophila AQ508 rabbit serum in agglutination titers against FKC and HKC of 25 strains of $A$. hydrophila. 

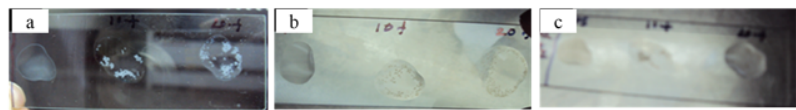

Figure 3: Slide agglutination test; (a) FKC of MTi811 agglutinated in 10and 20-fold dilution of the antiserum; (b) FKC of GP711 agglutinated in 10- but not 20 -fold dilution of the antiserum and (c) FKC of DV711 was not agglutinated in 10 - and 20 -fold dilution of the antiserum.

The possible reason would be the different environmental conditions and also the different immune system. In an earlier experiment, Leblance et al. found A. hydrophila and A. sobria among 195 strains of Aeromonas like bacteria isolated from fishes [24]. He also found 76 strains were serologically grouped by tube agglutination with whole cells antigen and anti-whole cell antiserum. Ramon et al. reported that there were different serotypes among A. hydrophila strains isolated from healthy fishes [25]. Previously Rashid reported different serotypes of Edwardsiella tarda strains isolated from healthy eels and their environment [17]. In another findings, among 62 strains of $E$. tarda, 56 strains showed positive result in 10- and 20 -fold dilutions of antiserum, were belonged to A-serotype. On the other hand, 3 strains were positive in 10 -fold but negative in 20 -fold dilution of the serum in slide agglutination test with an anti-E. tarda (NUF251) rabbit serum [26].

It is very important to develop vaccines against Aeromonas infection in fishes. Since, resistance capacity varies and there has been tremendous increase in the resistance after introducing antibiotics [27]. The serogrouping of bacterial strains within a genus is determined by the structural variability of surface polysaccharides. Strength of the titer can be administered during pre or post occurrence of fish diseases caused by $A$. hydrophila.

\section{Conclusion}

In the current investigation, it is clearly established that serotype is differ from region to region and among fish species as well. It is evident that serotype is one of the essential counterparts, which can be used with a view to controlling diseases caused by A. hydrophila. In order to control the disease effectively, ultimate users are therefore advised to use appropriate doses of prepared bactericide by keeping in mind about the serotype. So, this experiment will be very useful for the further development of antibiotics as well as vaccination against $A$. hydrophila.

\section{Acknowledgement}

Gratitude belongs to Prof. Dr. M. Mamnur Rashid, Department of Aquaculture, Bangladesh Agricultural University, Mymensingh, Bangladesh for his boundless supports and encouragements to accomplish this research.

\section{References}

1. Hossain MF, Rashid MM, Sayed MA (2011) Experimental INFECTION of climbing perch, Anabas testudenius with Aeromonas hydrophila bacteria. Progress Agric 22: 105-114.

2. Roberts RJ (1989) Fish pathology.

3. Cantas L, Sorby JR, Alestrom P, Sorum H (2012) Culturable gut microbiota diversity in zebrafish. Zebrafish 9: 26-37.

4. Trust TJ, Sparrow RA (1974) The bacterial flora in the alimentary tract of freshwater salmonid fishes. Canadian J of Microbiology 20: 1219-1228.

5. Suthi G (1991) Pathogenicity of motile Aeromonas for Puntius schwanfeldi and Oreochromis niloticus with particular reference to the ulcerative disease syndrome (EUS).

6. Chowdhury MBR, Muniruzzaman M, Zahura UA, Habib KZA, Khatun MD (2003)
Ulcer type of disease in the fish of small-scale farmer's pond in Bangladesh Pakistan. J Biological Sci 6: 544-550.

7. Subaskumar R, Thayumanavan T, Thilagavathy C, Vivekanandhan G Savithamani K, et al. (2006) Typing of haemolytic and Antibiotic resistant Aeromonas hydrophila isolated from raw milk of Coimbatore South India. Int J Dairy Sci 1: 70-83.

8. Porteen K, Agrawal RK, Bhilegaonkar KN (2007) Detection of Aeromonas spp. from Chicken and fish samples by polymerase chain reaction. American Journal of Food Technology 2: 30-37.

9. Cascon A, Anguita J, Hernanz C, Sanchez M, Fernandez M, et al. (1996) Identification of Aeromonas hydrophila hybridization group 1 by PCR assays. Applied and Environmental Microbiology 6: 1167-1170.

10. Sarker MGA, Chowdhury MBR, Faruk MAR, Uddin MN, Islam MJ (2000) Effect of water temperature on the infectivity of Aeromonas hydrophila isolates. Bangladesh J Fish 23(2): 99-105.

11. Dipu MRK (2012) Aqua drugs and chemicals use in aquaculture.

12. Janda JM, Abbott SL (1995) Human Pathogens. John Wiley and Sons Ltd Chichester, England.

13. Altwegg M (1999) Aeromonas and Plesiomonas. ASM Press, Washington DC.

14. Roberts RJ, Frerichs GN, Millar SD (1992) Epizootic ulcerative syndrome - the current position. Asian Fisheries Society Manila.

15. Khan MR, Rahman MM, Shamsuddin M, Islam MR Rahman M (2011) Present status of aqua-drugs and chemicals in Mymensingh district. J Bangladesh Society for Agricultural Sci and Tech 8: 169-174.

16. Engvall E, Perlmann P (1972) Enzyme-linked immunosorbent assay ELISA III Quantitation of specific antibodies by enzyme-labelled anti-immunoglobulin in antigen-coated tubes. Journal of Immunology 109: 129-135.

17. Rashid M (1997) Studies on Edwardsiella tarda infection in Japanese Flounder Paralichtys Olivaceus.

18. Sugahara K, Eguchi M (2012) The use of warmed water treatment to induce protective immunity against the bacterial cold-water disease pathogen Flavobacterium psychrophilumin ayu (Plecoglossus altivelis). Fish and Shellfish Immunology 32: 489-493.

19. Schubert HW, Kexelg (1964) Failure of Butanedioldeshydrogenase - Reaktionb ei some Pseudomonadacen and vibrio Zentralblatt fiir. Bacteriology parasites infectious disease and Hygiene 194: 130-132.

20. VÉron M, Gasserf (1963) On the detection of l' hydrogkne sulfure produit par certaines entirobacteriacees dans les milieux dits of Diagnostic quickly Annals of I'Institut Pasteur 105: 524-534.

21. Rakib SM (2011) Production of Anti-Aeromonas hydrophila rabbit serum.

22. Sabur MA (2006) Studies on the ecology of the pathogenic bacteria Aeromonas hydrophila in indigenous and exotic carps under polyculture condition.

23. Leblance DKR, Mittal G, Oliver, Lillier R (1991) Studies on Serotyping of Motile Aeromonas Species Isolated from Healthy and Moribund Fish Department of Pathology and Microbiology.

24. Ramon IA, Ma Guadalupe AA, Armando NO, Silvia GC, Miroslava SM (2006) Serogroups K1 antigen and antimicrobial resistance patterns of Aeromonas spp. Strains isolated from different sources in Mexico. Mem inst Oswaldo Cruz Rio de Janeiro 101: 157-161.

25. Minagawa, Park (1983) A study of certain Heterotrophic Polarly Flagellate Water Bacteria: Aeromonas, Pseudomonas and Comamonas. J Gen Microbiol 27: 121-133.

26. Cohen ML (1992) Epidemiology of drug resistance, implications for a post antimicrobial era. Science 257: 1050-1055.

27. Gold SG, Moellering RC (1996) Antimicrobial drug resistance. N Engl J Med 335: 1445-1453. 